\title{
Cutaneous Dendritic Cells Are Main Targets in Acute HIV-1-Infection
}

Ingrid Simonitsch, M.D., Alexandra Geusau, M.D., Andreas Chott, M.D., Wolfgang Jurecka, M.D. From the Institute of Clinical Pathology (IS, AC) and the Department of Dermatology, Division of Immunology, Allergy and Infectious Diseases (AG) and Division of General Dermatology (WJ), University of Vienna Medical School, Vienna, Austria

Acute human immunodeficiency virus (HIV) infection is a transient illness that typically presents with mucocutaneous and constitutional symptoms. It is soon followed by seroconversion with the detection of anti-HIV antibodies in the peripheral blood. To better understand the pathogenetic events leading to this clinical picture, we sought to investigate the (immuno)histologic features of the skin rash occurring in an acutely infected person. A skin biopsy of an acutely infected person was investigated histologically and immunohistologically using paraffinembedded tissue sections. Interface dermatitis with pronounced vacuolization of the basal keratinocytes was a prominent histological finding. The inflammatory infiltrate was composed of $\mathrm{CD3}+$ I CD8+ $T$ cells with coexpression of Granzyme B7 and TIA-1, and CD68+ histiocytes/dendritic cells. CD1a+ intraepidermal Langerhans cells (LC) were significantly decreased and individual LC coexpressed HIV-p24 antigens as evidenced in double labeling experiments. HIV-infected LC were demonstrated in close apposition to cytotoxic $\mathrm{T}$ cells.

This study provides the first definitive evidence for infection of LC at extramucosal sites in this very early stage of disease. Our findings emphasize the critical role of dendritic cells as a virus reservoir and the skin as a major site of HIV replication during the course of the disease.

KEY WORDS: Acute HIV infection, Immunohistochemistry, Langerhans cells.

Mod Pathol 2000;13(12):1232-1237

Copyright $\odot 2000$ by The United States and Canadian Academy of Pathology, Inc.

VOL. 13, NO. 12, P. 1232, 2000 Printed in the U.S.A.

Date of acceptance: June 21, 2000.

Address reprint requests to: Ingrid Simonitsch, M.D., Institute of Clinical Pathology, University of Vienna Medical School, General Hospital Vienna, Waehringer Guertel 18-20, A-1090 Vienna, Austria; e-mail: ingrid.simonitsch@akh-wien. ac.at; fax:: (+43-1) 4053402 .
Fifty to $80 \%$ of the patients infected with human immunodeficiency virus (HIV) suffer from an acute mononucleosis-like illness, with the skin and the oral mucosa being the most frequently involved sites (1, 2). This transient symptomatic illness is associated with a high-titered HIV-1 replication accompanied by an expansive immunologic response to the invading pathogen, mainly sustained by CD8 $+\mathrm{T}$ cells specifically targeted against the virus (3). Although virusspecific cytotoxic T cells play a major role in controlling the viral replication, it is conceivable that they may also contribute to certain symptoms of HIV disease. Similar to the observation that cytotoxic T cells directed against virus peptide-expressing hepatocytes are responsible for the liver necrosis seen in persons infected with the hepatitis B virus (4), it seems that the antiviral immune response plays a major role in the pathogenesis of the lymphocytic alveolitis of HIVinfected patients (5). Little is known, however, about the cellular events that take place in the skin during acute HIV-1 infection. Here, we report on the clinical and laboratory data as well as the (immuno)histologic findings of a skin lesion of a patient with primary HIV infection, and, based on these results, construct a concept concerning the pathogenesis of acute HIV exanthema.

\section{CASE REPORT}

In February 1998, a 24-year-old homosexual man, who had recently started a new relationship, developed constitutional symptoms, fever, lymphadenopathy, and a maculopapular skin rash predominantly on the trunk (Figure 1a) and face; additionally, conjunctivitis, cytomegalovirus (CMV)- and herpes simplex virus (HSV)- negative aphthous stomatitis (Figure 1b), as well as candidal esophagitis (diagnosed by gastroscopy), were observed. Laboratory findings showed slightly elevated liver enzymes, thrombopenia $(71 \mathrm{~g} / \mathrm{L}$; reference range, 140 to $440 \mathrm{~g} / \mathrm{L})$, and leucopenia (3.0 g/L, reference range, 4.3 to $10.0 \mathrm{~g} / \mathrm{L}$ ). An HIV-antibody test (enzyme-linked immunosorbent assay and Western-blot) was negative, as were 


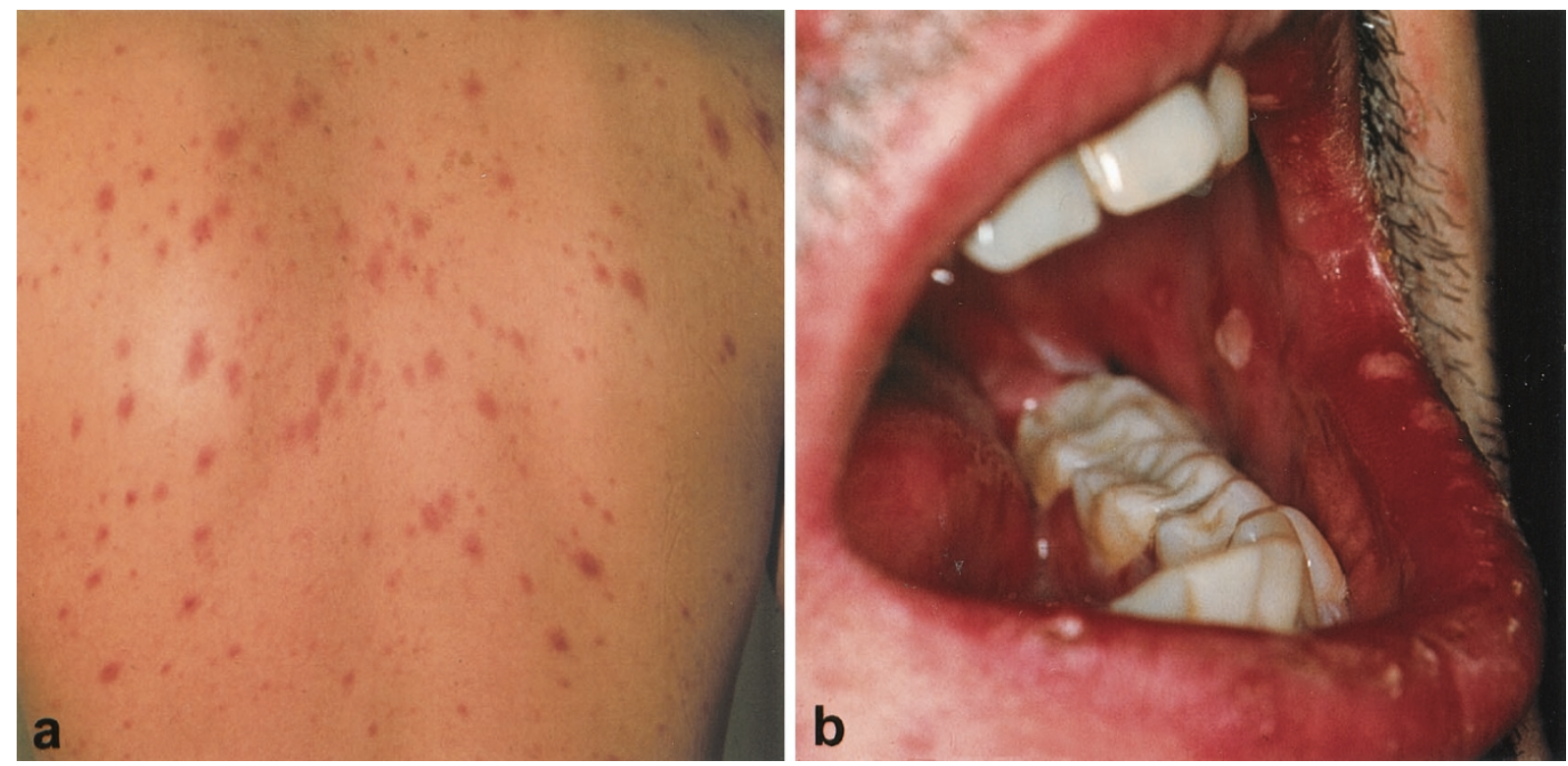

FIGURE 1. A, widespread maculopapular HIV exanthema. B, oral enanthema with ulceration.

serological tests for syphilis. The suspected diagnosis of a primary HIV infection could be established by a highly elevated p24 antigen test $(650 \mathrm{pg} / \mathrm{mL}$, Innotest HIV-1 p24-Ag assay) as well as by the detection of HIV-1 ribonucleic acid $\left(6.3 \times 10^{5}\right.$ copies $\left./ \mathrm{mL}\right)$ using the reverse transcriptase (RT)-polymerase-chainreaction (PCR) method (Amplicore HIV-1 monitor test). The patient's CD4 count was decreased $(400 / \mu \mathrm{l})$ and his CD4/CD8 lymphocyte ratio was reversed (0.66). Because antiretroviral treatment (ART) given early during primary HIV infection provides shortand long-term clinical benefit for the patient and may help to preserve immune function (6), a triple combination therapy (ritonavir $2 \times 400 \mathrm{mg}$, didanosine $2 \times 200 \mathrm{mg}$, stavudine $2 \times 40 \mathrm{mg}$ ) (7) in combination with a cytostatic agent (Hydroxycarbamide $2 \times 500$ $\mathrm{mg}$ ) was initiated. The patient's symptoms resolved within 1 week. Seroconversion to HIV could be demonstrated within 2 weeks of onset of the symptoms. After an initial rise of the viral load (more than $7.5 \times$ $10^{5}$ copies $/ \mathrm{mL}$ ), a steady decline could be documented within the following weeks after initiation of antiretroviral treatment. The viral load fell to a level below the detection limit of the test-system (Amplicore: 200 copies $/ \mathrm{mL}$ ) 6 months after seroconversion.

\section{MATERIAL AND METHODS}

\section{Histology and Immunohistochemistry}

A skin biopsy was taken from an erythematous plaque on the trunk. The specimen was fixed in $7.5 \%$ formalin, embedded in paraffin, and processed for routine histopathologic examination. Vertical sections (3 $\mu \mathrm{M}$ thick) were stained with hematoxylin and eosin (H\&E), Giemsa, and periodic acid-Schiff. For immunohistochemical examination, $2-\mu \mathrm{m}$ thick, paraffin-embedded serial sections were stained, applying a sensitive three-step immunoperoxidase technique exactly as described previously (8). The primary monoclonal (mAb) and polyclonal antibodies, their specificity, and the pretreatment procedures required are listed in Table 1. A double-staining method (9) was used to clarify the relationship between HIV-infected cells and either Langerhan's cells (LC; p24/CD1a) or cytotoxic cells (p24/GB-7). An immunoperoxidase method was used for both CD1a and GB-7 staining, and the antigen-antibody complex was visualized (in red) with aminoethyl carbazole/hydrogen peroxide. Then, either CDla- or GB-7- stained sections were further incubated with the anti-p24-antibody, washed and subjected to an immunoalkaline phosphatase labeling procedure; the staining was developed with the Vector-Blue Alkaline Phosphatase Substrate Kit III (Vector, Burlingame, CA), which gave a blue staining product. Negative controls were performed by applying irrelevant isotypematched mAbs as first-step reagents.

\section{Quantification of Intraepidermal LC}

The number of intraepidermal LC was determined by counting CDla + cells within the whole epidermis, regardless of epidermal thickness, in eight nonserial sections. The individual values obtained with CDla in each section were then pooled, and the mean number of LC per linear millimeter of the epidermal basement membrane was determined. 


\begin{tabular}{|c|c|c|c|c|c|}
\hline Antibody & $\mathrm{CD}$ & Specificity & Pretreatment & Dilution & Source \\
\hline CDla & CDla & LC, cortical thymocytes & MW & Conc. & IT \\
\hline CD4 & CD4 & Helper/inducer T cells; monocyte subset & AC & $1: 20$ & NC \\
\hline MT1 & CD43 & Leukosialin & - & $1: 80$ & BT \\
\hline Leu7 & CD57 & NK cell subset; T cell subset & - & $1: 10$ & $\mathrm{BD}$ \\
\hline KiMlp & CD68 & Macrophages/Dendritic cells & ED & $1: 50$ & * \\
\hline HECA- & - & CLA; skin-homing T cells; LC-subset & $\mathrm{ED}$ & $1: 250$ & PG \\
\hline TIA-1 & - & Cytotoxic granules & MW & $1: 400$ & $\mathrm{C}$ \\
\hline$\beta \mathrm{F} 1$ & - & T Cell Receptor (TCR) $\alpha / \beta$ & ED & $1: 10$ & EG \\
\hline CD3 & CD3 & T cells; CD3 complex associated with TCR & ED & $1: 400$ & Dako \\
\hline CD8 & CD8 & Cytotoxic T cells; NK cell subset & AC & $1: 30$ & Dako \\
\hline p24 & - & HIV p24-antigen & MW & $1: 10$ & Dako \\
\hline CD79a & CD79a & B cells (B cell receptor complex) & MW & $1: 25$ & Dako \\
\hline L26 & CD20 & B cells & - & $1: 200$ & Dako \\
\hline GB-7 & - & Granzyme B-7; activated cytotoxic lymphocytes & MW & $1: 20$ & MS \\
\hline CD5 & CD5 & T cells; B cell subset & $\mathrm{AC}$ & $1: 20$ & NC \\
\hline S100 & - & S100 protein; LC, melanocytes, neuronal & MW & $1: 600$ & HCS \\
\hline NCAM & CD56 & NK cells; some T cells & AC & $1: 200$ & MS \\
\hline $\begin{array}{l}\text { HLA- } \\
\text { DR }\end{array}$ & - & MHC class II & MW & $1: 200$ & Dako \\
\hline
\end{tabular}

MW, microwave; AC, autoclave; ED, enzymatic digestion; IT, Immunotech, Marseille, France; Dako, Dako, Glostrup, Denmark; NC, Novocastra, New Castle, UK; BT, Biotest, Dreieich, Germany; BD, Becton-Dickinson, San Diego, CA, USA; *, a kind gift of Prof. M. R. Parwaresch, Kiel, Germany; PG, Pharmingen, San Diego, CA, USA; C, Coulter, Hialeah, FL, USA; MS, Monosan, Uden, the Netherlands; HCS, HCS, Toronto, Canada.

\section{RESULTS}

\section{Histology (Figure 2)}

The epidermis presented with focal but pronounced parakeratosis and slight acanthosis. Additionally, spongiosis and diffuse vacuolization of the basal cell layer, together with several dyskeratotic keratinocytes, were identified (Figure 2, a and b), some of the latter in close contact to epidermal lymphocytes ("satellite cell necrosis") (Figure 2b). There was a dense perivascular and periadnexal mononuclear infiltrate within the papillary dermis with exocytosis. Hair follicles (Figure 2c) and sebaceous glands were heavily infiltrated with lymphocytes and histiocytes, leading to the partial destruction of these structures. The deeper reticular dermis

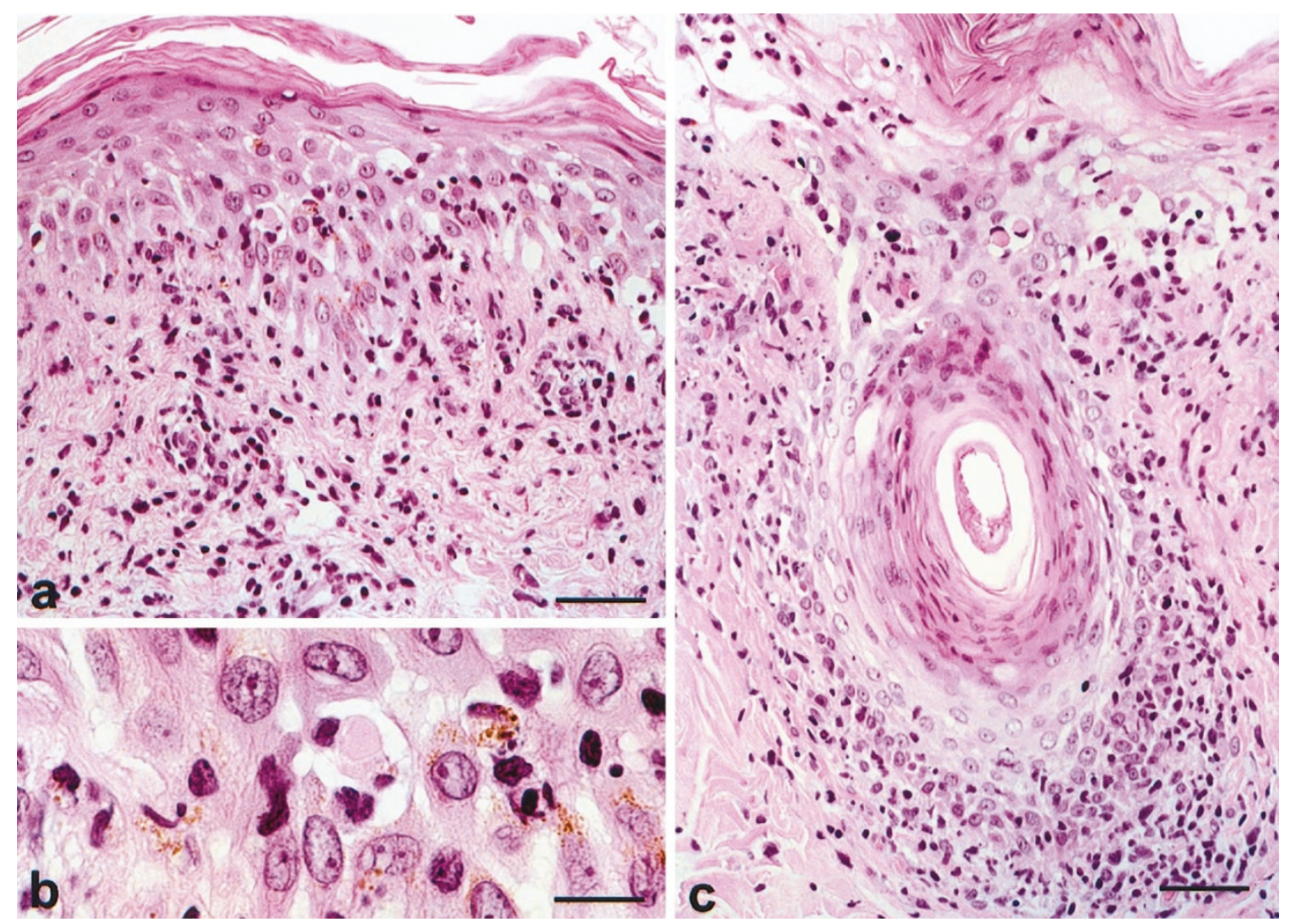

FIGURE 2. A-C, Light-microscopy. A, interface dermatitis with individual necrotic keratinocytes, lymphocytic exocytosis. H\&E staining, $\times 20$; B, several lymphocytes surrounding one necrotic keratinocyte ("satellite cell necrosis"). H\&E staining, $\times 60$. C, one hair follicle with heavy lymphocytic infiltration, the above epithelium with necrosis and vacuolization of keratinocytes. H\&E staining, $\times 20$. 
and the subcutaneous fatty tissue were almost devoid of an inflammatory infiltrate.

\section{Immunohistochemistry (Figure 3)}

\section{Epidermis}

Staining for CD3 (Figure 3a), CD5, $\beta \mathrm{F} 1$, and CD43 revealed that $\sim 50 \%$ of intraepithelial cells represented T cells with expression of the TCR $\alpha / \beta$. CD8+ $\mathrm{T}$ cells considerably predominated over $\mathrm{CD} 4+\mathrm{T}$ cells (data not shown); these CD8+ cells were reg- ularly observed in the vicinity of injured or dead keratinocytes. Almost all CD8 $+\mathrm{T}$ cells also reacted with the antibodies GB-7 (Figure 3b) and TIA-1, respectively, both antibodies providing a strong granular intracytoplasmic staining-product. Staining with the mAb HECA-452 revealed only single reactive cells within the epidermis, some of which corresponded to LC. Numerous CD68+ cells were also observed within areas of spongiotic epithelium (Figure 3d), some of them with a dendritic shape. Numbers of CDla+/S100+ LC (mean value, 2 LC
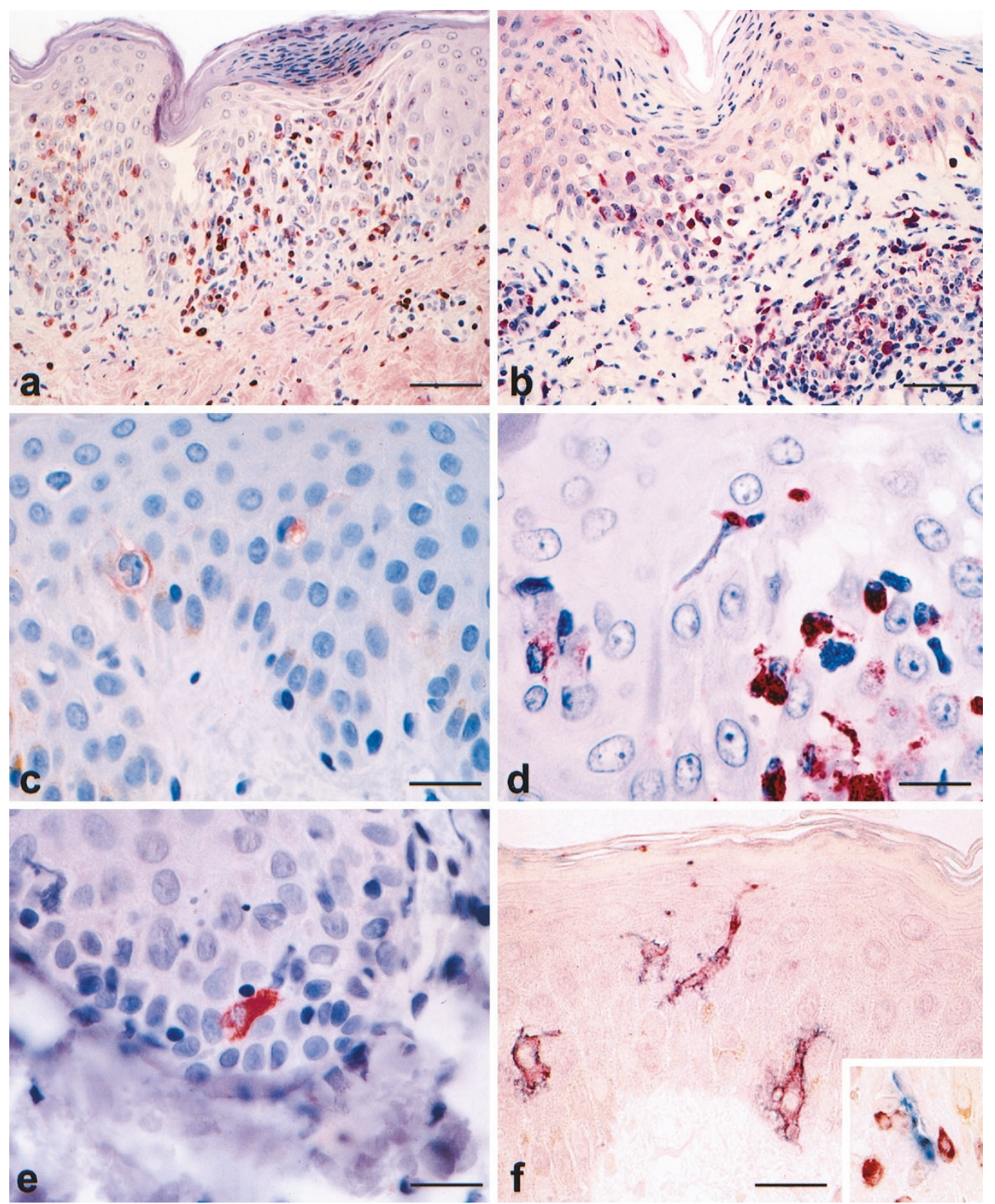

FIGURE 3. A-F, Immunohistology: A, abundant epidermal and dermal CD3+ T cells $(\times 20)$; B, most of the $T$ cells are also GB-7 reactive, indicating an activated, cytotoxic T cell phenotype $(\times 20)$. C, CDla + LC are significantly decreased and show degenerative morphologic changes $(\times 40)$. D, abundant intraepidermal CD68+ cells, some of them with a dendritic shape. E, one LC reactive for anti-p24-antibody $(\times 60)$. F, double staining of DC co-expressing CD1a (red staining) and p24 (blue staining); inset: GB-7+ cytotoxic T cells (red staining) in apposition with a p24-reactive DC (blue staining) $(\times 60)$. 
per millimeter of length of the epidermal basement membrane) were significantly reduced (Figure 3c) compared with normal skin (10). Their morphology was usually intact; occasionally, however, only rests of the dendrites were discernible. The MHC class II expression of LC could hardly be evaluated because most basal and suprabasal keratinocytes reacted with the anti- human leukocyte antigen-DR antibody. Concerning the occurrence of HIV-infected cells, we regularly noted a few p24 + cells. They most likely represented LC because of their dendritic shape (Figure 3e) and, as seen on serial- and double-stained sections, their anti-CDla-reactivity (Figure 3f).

\section{Dermis}

The dermal infiltrate was composed of approximately equal amounts of CD3 $+\mathrm{T}$ cells, CD4 + or CD8+ in similar quantities, and CD68+ histiocytes/ dendritic cells (DC) near each other. Approximately $50 \%$ of $\mathrm{T}$ cells co-expressed HECA-452. Most of the CD8 $+\mathrm{T}$ cells were positive with GB-7 and TIA-1. Single CDla + " dermal LC/DC were located below the dermo-epidermal junction and around the papillary vessels. No CD56+ or CD57+ natural killer cells were seen. CD79a or CD20-positive B cells/ plasma cells were only sparsely intermingled within the perivascular and interstitial infiltrate. Distinct perivascularly located mononuclear cells with dendritic morphology and cells within a densely infiltrated hair follicle were stained with mAb p24. Cytotoxic GB-7+ $\mathrm{T}$ cells were frequently found in direct apposition to p24+ DC (Figure 3f, inset), as evidenced in double-labeling experiments.

\section{DISCUSSION}

In this report on an acute symptomatic HIVinfection, we show that epithelial LC are productively infected already at this very early stage of disease. In 1987, Tschachler et al. (11) were the first to report on the presence of epidermal LC harboring HIV-p24 antigens in skin biopsies of HIVinfected persons. Consecutively, several groups have demonstrated that LC of squamous epithelia isolated from persons infected with HIV harbor HIV-1 proviral DNA and ribonucleic acid (12-14), indicating productive infection by the virus in vivo.

Evidence exists that infected skin-derived DC initiate massive viral replication in $\mathrm{CD} 4+\mathrm{T}$ cells in vitro (15). Subsequently, it has also been shown in vivo that the interaction of DC and T cells in the mucosa of tonsils and adenoids may support HIV-1 replication, even in nonsymptomatic periods of the infection (16). These results suggest that LC, once infected, represent a reservoir for the sustained infection of T cells. So far, where and when LC ac- quire HIV infection has not been elucidated. LC precursors migrate from the bone marrow via the peripheral blood first to the dermis and then to the epidermis. Therefore, infection may occur either within the bone marrow or the peripheral blood or, finally, within the skin. Infection of LC precursors in the bone marrow seems to be rather unlikely, because a nonhomogeneous spatial distribution of HIV-1 quasispecies has recently been demonstrated in epidermal LC of different skin-patches of one patient with AIDS (17). If LC precursors had been already infected within the bone marrow, the sequences detected in the different skin samples should have been similar, which was not the case in this study. These findings suggest that the infection of LC takes place in the skin, presumably when the LC precursors pass through the dermis.

One can assume that LC play an important role in the sexual transmission of HIV, because mucosal squamous epithelia of the cervix and the oral mucosa harbor numerous LC susceptible for HIV infection, thereby representing prominent cellular targets for the virus (18). Our results suggest that infection of nonmucosal epidermal LC, which are not likely to be infected through direct viral exposure, takes place very early during the disease, and may even precede seroconversion. In this instance, the infection is most likely accomplished by HIV-1infected CLA + memory T cells, which release virions by interacting with skin-homing LC.

We have also shown that the majority of these lymphocytes belong to the CD8+ subset. Concerning the functional consequences of the interaction between HIV-infected LC/DC and CD8+ lymphocytes, two mutually nonexclusive scenarios are conceivable. First, it is quite likely that some of these CD8 + cells are HIV-specific and capable of lysing HIV-infected cells. Because we have shown that LC and dermal DC are the predominant p24+ cutaneous cell population in primary HIV infection, they may well be the primary target of these activated cytotoxic T cells. In keeping with this assumption is our observation of decreased LC numbers compared with normal human skin (10). In this context, it is noteworthy that immunohistological analyses of the skin rash of rhesus monkeys infected experimentally with SIV revealed changes strikingly similar to those seen in this study, including a reduction of the LC-population $(19,20)$.

Second, one must assume that some of the lymphocytes within the LC/DC-T cell conjugates are not HIV-1-specific but rather represent bystander cells recognizing various antigenic specificities, perhaps even self-moieties. When activated by LC/ DC, such autoreactive cells would produce cytokines (e.g., interferon- $\gamma$ ) and acquire lytic potential toward surrounding resident skin cells. In accordance with this hypothesis are our findings of an 
abundant human leukocyte antigen-DR expression of keratinocytes and of CD8+/GB-7+ lymphocytes in close proximity to damaged keratinocytes. Given the fact that, upon perturbation, keratinocytes can elaborate large amounts of proinflammatory cytokines (21), it is not unreasonable to assume that keratinocyte injury by CD8+ cells contributes greatly to the clinicopathological features of primary HIV-1-infection.

In brief, we have documented for the first time that cutaneous LC/DC are early cellular targets for HIV-1, even in extramucosal sites. These dendritic cells may be infected even before seroconversion, as documented in our patient. Our findings emphasize the critical role of DC as a virus-reservoir and the skin as a major site of HIV replication during the course of the disease.

\section{REFERENCES}

1. Kinloch-de Loës S, de Saussure P, Saurat JH, Stalder H, Hirschel B, Perrin LH. Symptomatic primary infection due to human immunodeficiency virus type 1: Review of 31 cases. Clin Infect Dis 1993;17:59-65.

2. Kahn JO, Walker BD. Acute human immunodeficiency virus type 1 infection. N Engl J Med 1998;339:33-9.

3. Borrow P, Lewicki H, Hahn BH, Shaw GM, Oldstone MBA. Virus-specific CD8+ cytotoxic T-lymphocyte activity associated with control of viremia in primary human immunodeficiency virus type 1 infection. J Virol 1994;68:6103-10.

4. Bertoletti A, Ferrari C, Fiaccadori F, Penna A, Margolskee R, Schlicht HJ, et al. HLA class I restricted human cytotoxic T cells recognize endogenously synthesized hepatitis B virus nucleocapsid antigen. Proc Natl Acad Sci USA 1991;88:10445-9.

5. Plata F, Autran B, Pedroza-Martins L, Wain-Hobson S, Raphael M, Mayaud C, et al.. AIDS-virus specific cytotoxic T lymphocytes in lung disorders. Nature 1987;328:348-51.

6. Kinloch-de Loës S, Hirschel B, Hoen B, Cooper DA, Tindall B, Carr A, et al.. A controlled trial of Zidovudine in primary human immunodeficiency virus infection. N Engl J Med 1995;333:408-13.

7. Lafeuillade A, Pellegrino P, Poggi C, Costers O, Prozofi N, Tamelet C. Triple drug combination in primary HIV-1 infection. IX International Conference on AIDS, Vancouver 1996 (abstract).

8. Chott A, Haedicke W, Mosberger I, Födinger M, Winkler K,
Mannhalter C, et al. Most CD56+ intestinal lymphomas are CD8+CD5- T-cell lymphomas of monomorphic small to medium size histology. Am J Pathol 1998;153:1483-90.

9. Eichmüller S, Stevenson PA, Paus R. A new method for double immunolabelling with primary antibodies from identical species. J Immunol Methods 1996;190:255-65.

10. Petzelbauer P, Wolff K. Effects of CsA on resident and passenger skin immune cells of normal skin and UV-induced erythema reactions. Br J Dermatol 1992;127:560-65.

11. Tschachler E, Groh V, Popovic M, Mann DL, Konrad K, Safai B, et al. Epidermal Langerhans cells-a target for HTLV-III/ LAV infection. J Invest Dermatol 1987;88:233-7.

12. Zambruno G, Mori L, Marconi A, Mongiardo N, De Rienzo B, Bertazzoni U, et al. Detection of HIV-1 in epidermal Langerhans cells of HIV-infected patients using the polymerase chain reaction. J Invest Dermatol 1991;96:979-82.

13. Giannetti A, Zambruno G, Cimarelli A, Marconi A, Negroni M, Girolomoni G, et al. Direct detection of HIV-1 RNA in epidermal Langerhans cells of HIV-infected patients. J Acquir Immune Defic Syndr 1993;6:329-33.

14. Compton CC, Kupper TS, Nadire KB. HIV-infected Langerhans cells constitute a significant proportion of the epidermal Langerhans cell population throughout the course of HIV disease. J Invest Dermatol 1996;107:822-6.

15. Pope M, Betjes MGH, Romani N, Hirmand H, Cameron PU, Hoffman L, et al. Conjugates of dendritic cells and memory $\mathrm{T}$ lymphocytes from skin facilitate productive infection with HIV-1. Cell 1994;78:389-98.

16. Frankel SS, Wenig BM, Burke AP, Mannan P, Thompson LDR, Abbondanzo SL, et al. Replication of HIV-1 in dendritic cell-derived syncytia at the mucosal surface of the adenoid. Science 1996;272:115-7.

17. Sala M, Zambruno G, Vartanian JP, Marconi A, Bertazzoni U, Wain-Hobson S. Spatial discontinuities in human immunodeficiency virus type 1 quasispecies derived from epidermal Langerhans cells of a patient with AIDS and evidence for double infection. J Virol 1994;68:5280-3.

18. Lehner T, Hussain L, Wilson J, Chapman M. Mucosal transmission of HIV. Nature 1991;353:709.

19. Ringler DJ, Hancock WW, King NW, Letvin NL, Daniel MD, Desrosiers RC, et al. Immunophenotypic characterization of the cutaneous exanthem of SIV-infected rhesus monkeys. Am J Pathol 1987;126:199-207.

20. Sasseville VG, Rottman JB, Du Z, Veazey R, Knight HL, Caunt $\mathrm{D}$, et al. Characterization of the cutaneous exanthem in macaques infected with a nef gene variant of SIVmac239. J Invest Dermatol 1998;110:894-901.

21. Luger TA, Bhardwaj RS, Grabbe S, Schwarz T. Regulation of the immune response by epidermal cytokines and neurohormones. J Dermatol Sci 1996;13:5-10. 